\title{
Front Matter: Volume 8122
}

, "Front Matter: Volume 8122," Proc. SPIE 8122, Tribute to Joseph W. Goodman, 812201 (23 September 2011); doi: 10.1117/12.912647

SPIE Event: SPIE Optical Engineering + Applications, 2011, San Diego, California, SPIE. United States 


\section{PROCEEDINGS OF SPIE}

\section{Tribute to Joseph W. Goodman}

H. John Caulfield

Henri H. Arsenault

Editors

21-22 August 2011

San Diego, California, United States

Sponsored and Published by

SPIE 
The papers included in this volume were part of the technical conference cited on the cover and title page. Papers were selected and subject to review by the editors and conference program committee. Some conference presentations may not be available for publication. The papers published in these proceedings reflect the work and thoughts of the authors and are published herein as submitted. The publisher is not responsible for the validity of the information or for any outcomes resulting from reliance thereon.

Please use the following format to cite material from this book:

Author(s), "Title of Paper," in Tribute to Joseph W. Goodman, edited by H. John Caulfield, Henri H. Arsenault, Proceedings of SPIE Vol. 8122 (SPIE, Bellingham, WA, 2011) Article CID Number.

ISSN 0277-786X

ISBN 9780819487322

Published by

SPIE

P.O. Box 10, Bellingham, Washington 98227-0010 USA

Telephone +1 3606763290 (Pacific Time) · Fax +1 3606471445

SPIE.org

Copyright () 2011, Society of Photo-Optical Instrumentation Engineers

Copying of material in this book for internal or personal use, or for the internal or personal use of specific clients, beyond the fair use provisions granted by the U.S. Copyright Law is authorized by SPIE subject to payment of copying fees. The Transactional Reporting Service base fee for this volume is $\$ 18.00$ per article (or portion thereof), which should be paid directly to the Copyright Clearance Center (CCC), 222 Rosewood Drive, Danvers, MA 01923. Payment may also be made electronically through CCC Online at copyright.com. Other copying for republication, resale, advertising or promotion, or any form of systematic or multiple reproduction of any material in this book is prohibited except with permission in writing from the publisher. The CCC fee code is 0277-786X/11/ \$18.00.

Printed in the United States of America.

Publication of record for individual papers is online in the SPIE Digital Library.

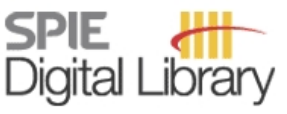

SPIEDigitalLibrary.org

Paper Numbering: Proceedings of SPIE follow an e-First publication model, with papers published first online and then in print and on CD-ROM. Papers are published as they are submitted and meet publication criteria. A unique, consistent, permanent citation identifier (CID) number is assigned to each article at the time of the first publication. Utilization of CIDs allows articles to be fully citable as soon as they are published online, and connects the same identifier to all online, print, and electronic versions of the publication. SPIE uses a six-digit CID article numbering system in which:

- The first four digits correspond to the SPIE volume number.

- The last two digits indicate publication order within the volume using a Base 36 numbering system employing both numerals and letters. These two-number sets start with 00, 01, 02, 03, 04 , $05,06,07,08,09,0 A, 0 B \ldots$. OZ, followed by 10-1Z, 20-2Z, etc.

The CID number appears on each page of the manuscript. The complete citation is used on the first page, and an abbreviated version on subsequent pages. Numbers in the index correspond to the last two digits of the six-digit CID number. 


\section{Contents}

$\checkmark$ Conference Committee

vii A Tribute to Joseph W. Goodman

ix Preface from Joseph W. Goodman

\section{SESSION 1}

812202 High-resolution imaging through horizontal path furbulence [8122-01]

W. T. Rhodes, D. Pava, F. Dalgleish, G. Nootz, S. R. Silva, Florida Atlantic Univ. (United States)

812203 Gigapixel synthetic-aperture digital holography [8122-02]

J. R. Fienup, A. E. Tippie, Institute of Optics, Univ. of Rochester (United States)

$812204 \quad$ Illustrative EDOF topics in Fourier optics [8122-03]

N. George, X. Chen, W. Chi, Institute of Optics, Univ. of Rochester (United States)

812205 Linear systems formulation of non-paraxial scalar diffraction theory [8122-04]

J. E. Harvey, CREOL, The College of Optics and Photonics, Univ. of Central Florida (United States)

812206 Fourier transforms by white-light interferometry: Michelson stellar interferometer fringes [8122-05]

J. B. Breckinridge, California Institute of Technology (United States) and College of Optical Sciences, Univ. of Arizona (United States)

812207 Coherence holography and photon-correlation holography: marriage between holography and statistical optics [8122-06]

M. Takeda, The Univ. of Electro-Communications (Japan); W. Wang, Heriot-Watt Univ. (United Kingdom); D. N. Naik, The Univ. of Electro-Communications (Japan)

812209 Fourier filtering grows much better with age [8122-08]

H. J. Caulfield, Fisk Univ. (United States)

\section{SESSION 2}

8122 OA Volume holographic spectral-spatial imaging of biological tissue [8122-09]

R. K. Kostuk, The Univ. of Arizona (United States) and College of Optical Sciences, The Univ. of Arizona (United States); J. K. Barton, College of Optical Sciences, The Univ. of Arizona (United States) and The Univ. of Arizona (United States); Y. Luo, Massachusetts Institute of Technology (United States); J. M. Castro, The Univ. of Arizona (United States); G. Barbastathis, Massachusetts Institute of Technology (United States)

$81220 \mathrm{C}$ Modern scalar diffraction theory [8122-11]

H. H. Arsenault, Univ. Laval (Canada); P. García-Martínez, Univ. de València (Spain) 
8122 OD Solar sails, optical tweezers, and other light-driven machines [8122-24]

M. Mansuripur, College of Optical Sciences, The Univ. of Arizona (United States)

8122 OE Fourier optics through the looking glass of digital computers [8122-13]

L. P. Yaroslavsky, Tel Aviv Univ. (Israel)

8122 OF Reflections on speckle: old and new results [8122-14]

C. Dainty, M. Chen, National Univ. of Ireland, Galway (Ireland)

\section{SESSION 3}

8122 OG Exploring light-matter interaction processes to appreciate various successes behind the Fourier theorem [8122-15]

C. Roychoudhuri, Univ. of Connecticut (United States)

$8122 \mathrm{OH}$ Singular beams in metrology and nanotechnology [8122-16]

J. Shamir, Technion-Israel Institute of Technology (Israel)

812201 Optical coherent processors in phase-space representations [8122-17]

J. Ojeda-Castañeda, C. M. Gómez-Sarabia, Univ. of Guanajuato (Mexico)

8122 OK Fourier optics and near-field superlens [8122-19]

Y. Sheng, G. Tremblay, Y. Gravel, Univ. Laval (Canada)

$8122 \mathrm{OL} \quad$ From Fourier optics to integrative engineering [8122-20]

T. Jannson, A. Kostrzewski, Physical Optics Corp. (United States)

$81220 \mathrm{M}$ Phase-sensitive coherence and the classical-quantum boundary in ghost imaging

[8122-21]

B. I. Erkmen, Jet Propulsion Lab. (United States); N. D. Hardy, D. Venkatraman, F. N. C. Wong,

J. H. Shapiro, Massachusetts Institute of Technology (United States)

$81220 \mathrm{~N}$ Digital holography and tissue dynamics spectroscopy: on the road to high-content drug discovery [8122-22]

D. D. Nolte, R. An, Purdue Univ. (United States); K. Jeong, Purdue Univ. (United States) and Korea Military Academy (Korea, Repulbic of); J. Turek, Purdue Univ. (United States)

POSTER SESSION

812200 Computational photography: advances and challenges [8122-23]

E. Y. Lam, The Univ. of Hong Kong (Hong Kong, China)

Author Index

iv 


\title{
Conference Committee
}

\author{
Conference Chairs \\ H. John Caulfield, Alabama A\&M University (United States) \\ Henri H. Arsenault, University Laval (Canada) \\ Session Chairs \\ 1 Session 1 \\ Henri H. Arsenault, University Laval (Canada) \\ 2 Session 2 \\ Jorge Ojeda-Castaneda, University de Guanajuato (Mexico) \\ 3 Session 3 \\ H. John Caulfield, Alabama A\&M University (United States)
}


Downloaded From: https://www.spiedigitallibrary.org/conference-proceedings-of-spie on 26 Apr 2023

Terms of Use: https://www.spiedigitallibrary.org/terms-of-use 


\section{A Tribute to Joseph W. Goodman}

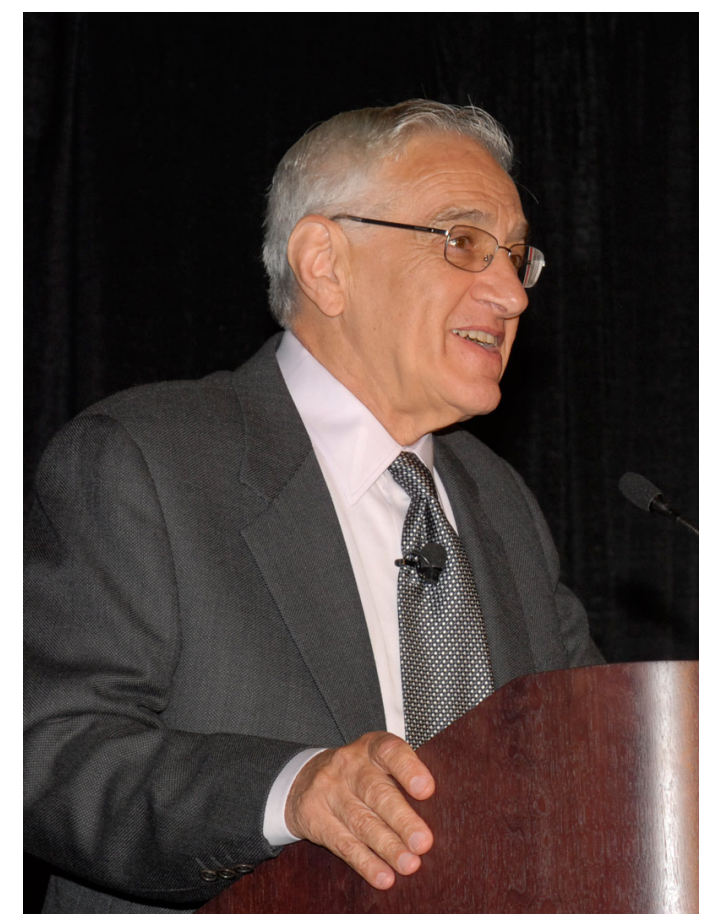

Professor Joseph W. Goodman's contributions celebrated by this conference extend not only to his writing, but also to his outstanding teaching and training of students who now range from academics through industry leaders to astronauts. His work has inspired contributions to this conference that range from applications in astrophysics to nanometer-scale devices, from theoretical developments to medical diagnostics.

Of course his best-known work is his book on Fourier optics, which has remained the standard bible on the subject for over 40 years. His seminal paper on speckle launched a whole new field and eventually led to his book on statistical optics, a field in which he is still active despite being retired from Stanford University. Many of his publications with his students were either major theoretical advances or the invention of devices or methods. 
Most of the speakers at this symposium were former students of Goodman's, or people who worked with him for a period of time. Certainly all claim to have been strongly influenced by Goodman's work.

Most of the publications of this symposium have a common thread which is Fourier optics. The application areas of Fourier optics seem surprisingly wide; after all, who would have predicted that Fourier optics would have applications in medical diagnostics and in aircraft black boxes?

This collection of articles should be a gold mine not only for researchers interested in the applications of Fourier Optics and Statistical Optics, but also for those interested in finding and understanding the relationships between seemingly widely separated areas of knowledge.

\section{H. John Caulfield Henri Arsenault}




\section{Preface from Joseph W. Goodman}

It has become a custom to mark certain birthdays as being especially significant, and I would like to thank SPIE for taking note of my 75th and honoring me with a special symposium. The presentations at this symposium are printed in this volume; they are contributions from many people, some of whom I have worked with when they were students, and some of whom I have simply admired and drawn inspiration from during my career. I would like to express my sincere thanks to all the participants for taking the time, not only to attend the symposium but also to prepare the written versions of their papers.

I first entered the field of optics after the completion of my Ph.D. in 1962. My thesis had dealt with microwave radar countermeasures using what at that time was called "communication theory." (The thesis ended up being classified from late 1962 through the year 2003.) The new commercial availability of HeNe lasers in 1962/63 raised questions about what they could be used for, and I was fortunate to have the opportunity to start research in optics at Stanford in 1963, motivated by this question. I soon discovered the classic papers of Leith and Upatnieks on a new type of holography, explanations for which usually invoked modulated high-frequency carriers, a subject with which I felt very much at home. I also soon discovered the work of Emil Wolf on coherence theory and Leonard Mandel on photoelectron counting statistics, both of which matched my background in statistical treatment of signals and noise. It was the previous work of all these individuals which aided me immensely in changing my field of research to optics.

There is no better way to learn a new subject than to try to teach it others. Fortunately, Stanford allowed me to define and teach a new graduate course, starting in about 1965, even though I was not a member of the faculty at that time (I was appointed to the faculty in 1967). I named that course "Introduction to Fourier Optics," and it was quite well attended. No textbook on the subject existed, so I wrote lecture notes for the class, and after two or three years of corrections of errors by the students in the class, I was able to turn those notes into a textbook with the same title as the class. Publication of this book had a major impact on my career.

One of the great advantages of being a faculty member at a first rate institution such as Stanford is the extremely high quality of the students that attend. Indeed I was fortunate to have a large number of excellent Ph.D. students (49 in all), many of whom went on to have outstanding careers in academia, industry, and 
government. I owe a great deal to those students, and I thank them for the fine work they have done and the friendships we have maintained over the years.

Finally, I owe special thanks to Henri Arsenault and John Caulfield, who organized the meeting, as well as to the SPIE staff who helped make it happen. I hope the reader will enjoy these papers.

Joseph W. Goodman 